\author{
Anna Babicka-Wirkus \\ Akademia Pomorska w Słupsku \\ E-MAIL: ankababicka@gmail.com
}

\title{
Polityka w edukacji i edukacja w polityce
}

\begin{abstract}
STRESZCZENIE
$\mathrm{W}$ artykule podejmuję problem uwikłania politycznego edukacji. Wskazuję na dialektyczność tego związku i ukazuję jego konsekwencję dla procesu emancypowania się podmiotu. Ramę teoretyczną prowadzonych rozważań stanowi teoria Jacques’a Rancière’a, w szczególności jego rozróżnienie dwóch sił mających znaczenie dla kształtu rzeczywistości społecznej. Mowa tu o policji i polityce. Pierwsza z nich wprowadza względny ład i pozorne bezpieczeństwo, druga natomiast - jest wydarzeniem kreującym chaos i niebezpieczeństwo, ponieważ prowadzi do nieprzewidywalnych zmian. Jest ona jednak kluczową siłą zmieniającą obowiązującą gramatykę szkoły, edukacji i społeczeństwa.
\end{abstract}

SŁOWA KLUCzOWE: edukacja, polityka, policja, ryzyko, Rancière

\section{Wprowadzenie}

W artykule analizuję kwestię relacji zachodzącej między polityką i edukacją. Skupienie się na związkach występujących między tymi kategoriami jest w kontekście współczesnych wydarzeń światowych i lokalnych szczególnie istotne i wymaga refleksji pedagogicznej. Omawiana relacja jest złożona i wielowymiarowa, dlatego też obliguje do dogłębnego zbadania i osadzenia w określonym kontekście społecznym, ekonomicznym i kulturowym. Jej charakter i jakość mają znaczenie dla kształcenia i wychowania obywateli nie tyle zsocjalizowanych, lecz zdesocjalizowanych (Czerepaniak-Walczak, 2009), którzy będą potrafili przełamywać obowiązujące schematy.

Wydarzenia społeczne ostatnich kilku lat utwierdzają badaczy (por. Matynia, 2018; Bruno and Downes, 2018; Babicka-Wirkus, 2018a; Rosenvallon, 2007), a także część opinii publicznej ${ }^{1}$ w przekonaniu, że mamy do czynienia z głębokim kryzysem społeczeństw demokratycznych i głoszonych przez nie

Ponad 52\% respondentów uznało po dwóch latach rządów partii Prawo i Sprawiedliwość, że ich dokonania są negatywne (Szaniawski, 2017). 
wartości. Przykładów tego typu sytuacji jest wiele, na przykład: kryzys związany z falą uchodźców zalewających kraje europejskie, powrót idei nacjonalistycznych, faszystowskich, ksenofobicznych, dążenie wielu rządów państw demokratycznych do usankcjonowania władzy absolutnej itp. Wszystkie te problemy spowodowały uruchomienie się $\mathrm{w}$ wielu krajach mechanizmów obywatelskiego nieposłuszeństwa, które w zetknięciu z dominacją logiki policyjnej przynoszą zazwyczaj niewielkie zmiany, ponieważ interpretowane są przez hegemoniczne siły jako niemające dużego znaczenia przejawy buty tych, którym odbierane są przywileje wimię arbitralnie definiowanej sprawiedliwości społecznej. Odmienne od usankcjonowanych przez siły policyjne głosy i opinie sprowadzane są do asemantycznych dźwięków, postrzeganych jako te, które albo nie mają znaczenia dla obowiązującego dyskursu publicznego, albo bezpośrednio mu zagrażają. W tym drugim przypadku są one interpretowane jako niebezpieczeństwo zagrażające obowiązującemu status quo.

W tak pokrótce zarysowanym kontekście społecznym kluczowa jest kwestia kierunku zmian współczesnej edukacji. Pojawiają się zatem pytania, czy współczesna edukacja powinna być polityczna, jeżeli tak, to w jakim sensie, jakie warunki powinny być stworzone, aby taka edukacja mogła być realizowana?

$\mathrm{W}$ celu zmierzenia się z zarysowanym polem problemowym należy najpierw zdefiniować, czym jest edukacja polityczna. Odwołując się do koncepcji polityki zaproponowanej przez Jacques'a Rancière’a (2007) definiuję ją jako proces wychowania i kształcenia, opierający się na równości żądania bycia wysłuchanym i na walce o uznanie za prawomocnego partnera w debacie. Tak rozumiana edukacja zakłada równość partnerów, a w szczególności równość intelektów wszystkich podmiotów uczestniczących w tym procesie. Zakłada ona również aktywność uczniów, którzy w bankowym podejściu do edukacji - obowiązującym obecnie - są postrzegani jako bierne przedmioty, którym przekazywana jest wiedza przez „oświeconych” nauczycieli. Bezkrytyczność i odtwórczość wpisana we współczesny system edukacji powszechnej w Polsce powinna zostać zastąpiona „uaktywnieniem” ucznia i umożliwieniem mu wypowiadania się, co Rancière (1991) uważa za podstawę jego upodmiotowienia.

Upominanie się o politykę w edukacji powodowane jest koniecznością wprowadzenia w jej ramy realnego dialogu między nauczycielem a uczniem, podczas którego jedna i druga strona będą mogły rozwijać swoje postrzeganie rzeczywistości i krytycznie się do niej odnosić. Jest to ważne ze względu na pobudzanie refleksyjności i umiejętności niepodporządkowywania się narzu- 
canym schematom. W trakcie edukacji jednostka powinna rozwinąć umiejętność odważnego wyrażania własnego zdania i sprzeciwu oraz uznania dla odmiennego sposobu analizy rzeczywistości. Tylko wówczas edukacja będzie przygotowywać do aktywnej partycypacji obywatelskiej i szacunku dla drugiego człowieka, który może być adwersarzem w postrzeganiu i wyjaśnianiu danego fragmentu rzeczywistości. Demokratyczne społeczeństwo bowiem oparte jest na aktywnym dialogu i szacunku dla odmiennego postrzegania. Nie jest to forma życia społecznego, wktórej wszyscy zgadzają się ze sobą i są jednomyślni. Pisze o tym Henry A. Giroux (Marzenie o edukacji..., 2010, s. 83), gdy stwierdza, że demokracja jest „polityką różnicy” bazującą na niezgodzie wynikającej z odmienności definiowania argumentowanego. Owa odmienność jest rezultatem posiadania innych doświadczeń, które są pokłosiem zajmowanej pozycji społecznej i pełnionych przez jednostkę ról społecznych.

Zaistnienie w przestrzeni dyskursu odmiennych poglądów, opinii, sposobów definiowania, sprzyja krytycznej refleksji nad istniejącą strukturą i może prowadzić do jej transformacji. Taka sytuacja stanowi swoiste wyzwanie dla współczesnej edukacji, która powinna się skupić na stworzeniu uczniom warunków nieskrępowanego zabierania głosu i wyrażania własnych poglądów. Jest to trudne zadanie, wymagające przeformułowania istniejących schematów kształcenia i wychowania. Jest ono jednak niezbędne dla uaktywnienia jednostek jako twórczych kreatorów rzeczywistości. Tak rozumiana edukacja umożliwia przełamywanie opresji hegemonicznych sił policyjnych i zderzenie ich z siłami politycznymi, co przyczynia się do włączania w istniejący dyskurs elementów dotychczas niedostrzegalnych. Prowadzi to do powstania sporów, które są podstawą istnienia społeczeństw demokratycznych. Podejmowane natomiast przez siły policyjne próby uczynienia tych sporów niedostrzegalnymi w ramach obowiązującego dyskursu są przejawami stosowania mechanizmów obronnych i podtrzymujących istniejący ład. Są zatem działaniami antydemokratycznymi, pozorującymi walkę o utrzymanie demokratycznych struktur w społeczeństwie.

\section{Spór jako kluczowy element edukacji}

Edukacja jest procesem zachodzącym pomiędzy biegunami skrajnego podporządkowania i skrajnego nieposłuszeństwa. Zazwyczaj lokuje się bliżej jednego lub drugiego krańca, co wynika z wzajemnej przenikalności władzy i oporu. Jak twierdzi Michel Foucault (2000): tam, gdzie jest władza jest też i opór. Jednak, za Lis Abu-Lughod (1990), można też powiedzieć, że występowanie oporu wiąże się z działaniem władzy. Trudno zatem oddzielić od siebie 
te dwa procesy. $Z$ tego też względu powinno się je rozpatrywać wspólnie w kontekście oddziaływań edukacyjnych, co czyni z tych ostatnich przedmiot polityki.

Według Rancière’a w społeczeństwie możemy odnaleźć dwie ścierające się ze sobą siły: policji i polityki. Zadaniem pierwszej jest podtrzymanie ustalonego porządku, a więc utrzymanie „rzeczy, aktywności i ludzi we właściwych im miejscach. Policją jest wszystko to, co blokuje przekraczanie granic i dyscyplin. (...) Policja określa układ tego, co widzialne, wyobrażalne i możliwe, powstały dzięki systematycznej produkcji tego, co dane, a nie poprzez spektakularne strategie kontroli i opresji” (Sztuka tego, co możliwe..., 2007, s. 157). Są to siły, które mają na celu neutralizację i uczynienie niedostrzegalnym tego, co ujarzmia podmiot. Przykładem zneutralizowanej opresji jest dyskutowanie o rasach czy o tożsamościach seksualnych, czyniąc punktem odniesienia w pierwszym przypadku rasę białą, a w drugim - tożsamość heteroseksualną. Są to reżimy, które, jak twierdzi Peter McLaren (2015, s. 355), dla osób będących ich reprezentantami stanowią nieuświadomioną oczywistość. Białość lub inny przejaw usankcjonowanej dominacji „[u]stanawia uniwersalizującą władzę, dzięki której biała burżuazja (lub inny przejaw hegemonii - dop. A.B.-W.) przypisuje sobie prawo przemawiania wimieniu wszystkich kolorowych (nieheteroseksualnych i innych mniejszości - dop. A.B.-W.), zarazem w imię cywilizacji odmawiając im prawa głosu i sprawstwa" (McLaren, 2015, s. 354). Za pośrednictwem procesu socjalizacji i edukacji jednostki uwewnętrzniają pewne kulturowo skonstruowane oczywistości, które stanowią punkt odniesienia dla wyborów moralnych.

Porządek funkcjonuje w społeczeństwie, ponieważ istnieją podmioty narzucające swój punkt widzenia i posiadające możliwość tworzenia dyskursu, któremu inni się podporządkowują, mimo że nie są jego kreatorami. Jednak, jak podkreśla Rancière (1999, s. 16): „aby podporządkować się dominującemu porządkowi, dwie rzeczy muszą zostać spełnione: należy go rozumieć i należy rozumieć, że trzeba mu się podporządkować”. Wymóg ten jest spełniany za pośrednictwem procesu edukacji i socjalizacji, podczas których jednostka nabywa wiedzę o tym, co „normalne” i co „dewiacyjne” oraz uczy się podporządkowania ustanowionym odgórnie autorytetom, wartościom i regułom. Jest to niezbędny element wrastania w kulturę i społeczność, w której się żyje. Wiedzę tę nabywamy poprzez obserwację, treści bajek czytanych dzieciom, fabuły różnych książek, filmów i inne środki masowego przekazu.

Zadaniem policji jest uczynienie otaczającej nas rzeczywistości zrozumiałą i przewidywalną, a co za tym idzie - względnie bezpieczną. Nie chodzi przy tym o dążenie do eliminacji wszelkich zagrożeń, a wręcz przeciwnie - o ich 
tworzenie. Policja za pośrednictwem dyskursu kreuje potencjalne zagrożenia w celu wzbudzenia wśród obywateli obaw i podejmowania działań nakierowanych na zapobieżenie im. Współcześnie są to takie zagrożenia jak: terroryzm, uchodźcy, czy szerząca się "plaga zabójstw nienarodzonych dzieci” (aborcja, niszczenie zarodków w procedurze in vitro). Kreowanie tego typu zagrożeń usprawiedliwia wprowadzanie i zaostrzenie procedur kontrolnych, co prowadzi do ograniczania podstawowych wolności obywateli.

Policja, zajmując się dystrybucją miejsc i funkcji społecznych (Rancière, 1999), jest w tym wymiarze egalitarna. Każdy w społeczeństwie posiada wyznaczone miejsce i pełni określoną funkcję. Jednak nie każdy ma możliwość decydowania o dystrybucji pozycji i zadań. Gert J.J. Biesta stosuje do interpretacji fenomenu policji określenie „all-inclusive” (2009, s. 108), co uwydatnia hierarchiczne rozdystrybuowanie pozycji wszystkich w strukturze społecznej. Nikt zatem nie jest wyłączony z obowiązującego porządku, nieliczni natomiast decydują o jego kształcie.

W kontekście omawiania funkcjonowania sił policyjnych ważne jest, aby podkreślić, że działają one w sposób niedostrzegalny. Są rozproszone, a przez to trudne do uchwycenia. Policja nie stosuje represyjnych mechanizmów ujarzmiania. Czyni to w sposób subtelny i często niedostrzegalny dla obywateli. Można więc określić ją mianem rozproszonej i kapilarnej (Drozdowski, 2009, s. 198)². Poza cechą niewidzialności policji, Jerzy Franczak (2017) - polski badacz myśli Rancière’a - wskazuje również na obiektywność, statyczność i opresyjność tej siły. Nie będę jednak przybliżać tu poszczególnych charakterystyk policji, ponieważ ich rozpatrywanie nie stanowi przedmiotu prowadzonych w tym artykule rozważań.

Kluczową natomiast dla prowadzonych tu analiz siłą jest polityka. Stanowi ona koło napędowe zmian społecznych. Jej zadanie sprowadza się do przeszkadzania w najprostszych formach dominacji (Rancière, 1999, s. 11) poprzez ich dekonstrukcję. Rancière wyraźnie wskazuje, że celem polityki nie jest odsłanianie tego co ukryte, ponieważ takie podejście zakładałoby ustanowienie pozycji panowania (Janusowe oblicze sztuki..., 2007, s. 165-166). Dekonstrukcja natomiast zakłada dokonanie odmiennych, często nieprzewidywalnych i wykraczających poza znane schematy interpretacji. Przez tego typu działania zmianie ulega obowiązujący dyskurs.

2 Obecnie R. Drozdowski wraz z M. Frąckowiakiem dostrzegli nowe tendencje socjologiczne w analizach współczesnej władzy, która zaczyna przyjmować postać zdekapilaryzowaną. Autorzy kreślą w swoich rozważaniach możliwe drogi rozumienia tego typu władzy, jednak nie określają definitywnie swojego stanowiska w tej kwestii, czyniąc tym samym problem nadal otwartym (Drozdowski, Frąckowiak, 2017). 
Polityka jest fenomenem, dla urzeczywistnienia się którego znaczące jest zaistnienie sytuacji równości. Według francuskiego filozofa (Janusowe oblicze sztuki..., 2007, s. 168)

polityka nie opiera się na równości (...). Równość jest w rzeczywistości warunkiem koniecznym do tego, by polityka była możliwa do pomyślenia. (...) Równość wytwarza politykę jedynie wówczas, gdy zostaje wprowadzona w specyficznej formie jakiegoś konkretnego sporu [dyssensus].

A zatem polityka przejawia się poprzez ustanowienie sporu, w którym uczestniczą na równi odmienne strony. Jest to możliwe, gdy logika policji spotyka się z logiką równości (Rancière, 1999). Dochodzi wówczas do upodmiotowienia, czyli transformacji tożsamości, które zostały narzucone przez porządek policyjny i umiejscowienie ich w doświadczaniu sporu. Przekroczeniu ulegają wyznaczone ramy i granice, co w konsekwencji prowadzi do usłyszenia głosu Innego (Rancière, 1999), który wcześniej sprowadzany był do asemantycznego hałasu. Zabieranie głosu powoduje wywłaszczanie przestrzeni dyskursu, który w ten sposób może ulec zmianie. „Bezustanna rekonfiguracja sensible (zmysłowego - dop. A.B.-W.) jest miejscem ustanawiania, negocjowania i podważania apriorycznych form poznawczych" (Franczak, 2017, s. 110).

Cechą polityki jest jej chwilowość i ulotność, co czyni z niej swoisty moment, wydarzenie, wznaczeniu, jakie temu terminowi nadał Alain Badiou (2010). Ożywia ono procesy interpretacyjne i narusza obowiązujące schematy, ukazując tym samym ich arbitralność. Za pośrednictwem polityki możliwy staje się świat odmienny od znanego. Jest to rzeczywistość, w której nie obowiązuje narzucona hierarchia i usankcjonowane przez policję dzielenie postrzegalnego. Na ten aspekt zwraca uwagę Slavoj Žižek (2007, s. 196), analizując filozofię Rancière’a. Słoweński socjolog i filozof stwierdza, że

Właściwa polityka wiąże się więc ze swojego rodzaju krótkim spięciem między uniwersalnością a partykularnością. (...) Konflikt polityczny zawiera się właśnie w napięciu między ustrukturyzowanym ciałem społecznym, gdzie, każda część ma swoje miejsce (...) oraz „częścią-bez-miejsca”, która zaburza ten porządek w imię pustej zasady uniwersalności, w imię tego, co Ėtienne Balibar nazywa égaliberté, zasadą równej wolności wszystkich ludzi jako istot mówiących.

Owo spięcie, o którym pisze Žižek jest momentem rekonfiguracji dzielenia postrzegalnego. Chodzi tu o konieczność zaistnienia niezgody, którą „Rancière rozumie (jako - dop. A.B.-W.) pewną sytuację słowa: taką, w której jeden lub więcej interlokutorów nie dostrzega tego, o czym mówi inny" (Fran- 
czak, 2017, s. 139). Niezgoda odnosi się tu głównie do tego, co jest argumentowane, a nie do procesu argumentacji. Bazuje na krytyce narzuconych narracji, które, odwołując się do analiz Jeana-François Lyotarda (1997), można nazwać „wielkimi opowieściami” legitymizującymi obowiązujący porządek społeczny. Podważenie naturalności ich obowiązywania prowadzi do zmiany i rekonfiguracji istniejącej struktury, ustanawianej przez modyfikację optyki dzielenia postrzegalnego.

Zaistnienie sporu jest kluczowe dla ukonstytuowania się stron konfliktu. Przed sporem bowiem owe strony nie istnieją. To właśnie konflikt nadaje im tożsamość społeczną. A zatem stają się one władne żądania bycia wysłuchanymi przez tych, którzy wcześniej, na mocy usankcjonowanego dzielenia postrzegalnego, ich nie słyszeli. Dochodzi zatem do konfrontacji dwóch światów w obrębie jednego (Rancière, 1999, s. 27). W wyniku tego działania następuje transformacja dzielenia postrzegalnego, ponieważ dostrzeżona została arbitralność i partykularność leżące u jego podstaw. Powstaje zatem inny porządek zmysłowego, który należy rozumieć jako tymczasowy, ponieważ może on ulec zmianie w wyniku pojawienia się kolejnego sporu (Rancière, 1999). Polityka zatem wprowadza chwilowy nieporządek i chaos wynikający z destabilizacji narzuconej struktury. Niesie ona zagrożenie i niepewność, co z kolei stanowi konstytutywne cechy ryzyka.

\section{(Nie)bezpieczne ryzyko}

Urlich Beck określił współczesne społeczeństwo mianem społeczeństwa ryzyka. Ten nowy model powstał w wyniku kumulacji zagrożeń wyłaniających się praktycznie z każdego obszaru naszego życia - rozpoczynając od skali mikro na skali mezo kończąc. Mimo że współczesny świat w porównaniu z przeszłością jest o wiele bardziej bezpieczny, to jego kluczowym problemem jest urynkowienie ryzyka (Beck, 2004). Jak twierdzi Beck (2012, s. 23):

Kategoria ryzyka oznacza zatem dyskusyjną realność możliwego (...). Ryzyka są zawsze wydarzeniami przyszłymi, możliwymi, grożacymi nam. Jednak to stałe zagrożenie określa nasze oczekiwania, opanowuje nasze myśli i kieruje naszymi lękami, i dlatego staje się siłą polityczną zmieniającą świat.

Kreowanie potencjalnych niebezpieczeństw jest domeną policji, która za pośrednictwem tego typu działań dąży do poszerzania zakresu podporządkowanych i zniewolonych ludzi. Operując logiką strachu, zwiększa kontrolę nad obywatelami i wprowadza pozorne poczucie bezpieczeństwa, ponieważ precyzyjnie określa „przyjaciół” i „wrogów” obowiązującego ładu. Jest to sprytna strategia mająca na celu zapewnienie iluzorycznego poczucia kontroli 
nad rzeczywistością i posiadania ugruntowanej wiedzy na jej temat. Takie działanie sprzyja wzrostowi poczucia sympatii wobec działalności policji, której celem jest ochrona obywateli przed zagrożeniami. Niezależnie jednak od tego, czy społeczność uznaje jedną opcję policji za lepszą, a drugą za gorszą - to zawsze mamy do czynienia z siłami opozycyjnymi wobec polityki (Rancière, 1999), które bazują na relacji dominacja-podporządkowanie.

Za pośrednictwem działania sił policyjnych opozycja wróg-przyjaciel ulega neutralizacji i staje się niepodważalną oczywistością. Jasne wyznaczenie granic między Nami i Nimi ułatwia funkcjonowanie społeczne jednostek, które są członkami różnych grup społecznych, zazwyczaj określających się w opozycji do grup przeciwników. Problem niosący zagrożenie dla tej usankcjonowanej relacji opozycyjnej pojawia się, jak wskazuje Zygmunt Bauman, gdy na scenę społecznego doświadczania wkracza Inny - Obcy. Autor (1991, s. 55), pisząc o relacji z Obcym, podkreśla, że „nie jest on ani przyjacielem, ani wrogiem; (...) może być oboma. (...) (Obawiamy się go - dop. A.B.-W.), ponieważ nie wiemy, i nie mamy sposobu, aby się dowiedzieć, co jest prawdą". $\mathrm{Z}$ taką samą sytuacją mamy do czynienia, gdy logika równości spotyka się z logiką policyjną, ponieważ wówczas ci, którzy wcześniej nie byli słyszalni zabierają głos i domagają się bycia wysłuchanymi oraz uczestnictwa w tworzeniu dyskursu społecznego. Jest to zatem zagrożenie dla istniejącego status quo, które nie musi być idealne, ale jest powszechnie znane i rozumiane. Wprowadzanie głosu Obcego, który wcześniej nie był rozpoznawalny, grozi natomiast dekonstrukcją, a nawet destrukcją znanej rzeczywistości. Z tego też względu policja stosuje szereg strategii mających na celu utrzymanie „zawłaszczonego miejsca” swojej dominacji. Jedną z częściej stosowanych strategii jest kreowanie potencjalnych niebezpieczeństw, które mogą czyhać, gdy „podwładni” zdecydują się wyłamać z obowiązujących schematów.

W interesujący sposób fenomen grania potencjalnymi zagrożeniami przedstawił Frank Furedi (2017), pisząc o współczesnej rzeczywistości uniwersytetów amerykańskich. Z obawy przed naruszeniem komfortu psychicznego studentów uczelnie stosują różne praktyki, aby zapobiec takim sytuacjom. Popadają przy tym w skrajności i prowadzą do wzrostu infantylizacji wśród studentów, którzy z obawy przed niewygodnymi treściami wykładów lub rozmów z Obcymi (reprezentantami mniejszości lub większości rasowych, seksualnych, wyznaniowych itp.) zamykają się we własnym „bezpiecznym” świecie, otoczeni tylko przyjemnymi i niewymagającymi wysiłku intelektualnego treściami i osobami. Kreując i podtrzymując lęk przed możliwym 
niebezpieczeństwem dyskomfortu poznawczego lub emocjonalnego, uniwersytety stwarzają realne zagrożenie kształcenia biernych i bezrefleksyjnych jednostek, które będą dążyć do podtrzymywania swojego dobrego samopoczucia i dalekie będą od angażowania się w sprawy problematyczne.

Opisany przez Furediego (2017) fenomen infantylizacji studentów występuje również na niższych szczeblach edukacji. Nauczyciele, wespół z Ministerstwem Edukacji Narodowej i nierzadko również rodzicami, kreują wśród uczniów potencjalne niebezpieczeństwo „wypadnięcia z wyścigu szczurów” i tym samym brak możliwości osiągnięcia sukcesu życiowego, jeśli nie zda się na odpowiednio wysokim poziomie testów kończących poszczególne etapy edukacji. Wszechogarniająca szkoły testomania prowadzi do „odstawienia na boczny tor” (na dalszy etap edukacji) dbałości o rozwój krytycznego myślenia, które jest kluczowe dla podważania obowiązujących reguł, schematów i norm. Jednak wytrenowanie w próbach „odgadnięcia właściwej odpowiedzi” i tego, „Co autor pytania miał na myśli”, zakorzenia się na tyle silnie w młodych umysłach, że prowadzi to do wdrożenia posługiwania się schematem, a nie łamania go.

Spotkanie z Obcym, jakkolwiek byśmy go nie ujęli, stwarza przestrzeń ryzyka związanego $\mathrm{z}$ utratą poczucia swojskości, stabilności. Jest to jednak konieczne dla zaistnienia zmiany wynikającej z transformacji czy nawet transgresji istniejącego porządku społecznego. Spotkanie z Obcym wymaga wysiłku intelektualnego, o który w edukacji upomina się Rancière. Zmusza do refleksji nad własną sytuacją i umożliwia dostrzeżenie innego świata, który również jest możliwy. Nie oznacza to, że należy bezrefleksyjnie przyjmować ów inny świat, lecz chodzi o refleksję nad swoim położeniem, które może okazać się nie aż tak komfortowe, jak wcześniej zakładaliśmy.

\section{$W$ ramach podsumowania: $O$ wzajemnym uwikłaniu edukacji i polityki}

Tytuł niniejszego artykułu oddaje polityczne uwikłanie edukacji, ponieważ $\mathrm{z}$ jednej strony edukacja jest przestrzenią, w której stwarzane są warunki dla zaistnienia polityki w rozumieniu Rancière’a, z drugiej jednak - za pośrednictwem momentów politycznych - dochodzi do oddziaływań edukacyjnych. W wyniku polityki zachodzi proces upodmiotowienia (Rancière, 1991), podczas którego jednostka uświadamia sobie arbitralność i tymczasowość swojego obecnego usytuowania w strukturze społecznej. Jest to zdaniem francuskiego filozofa kluczowe dla emancypowania się jednostki.

Rancière jednak, odmiennie niż Paulo Freire (2000) - uznany za klasyka myśli emancypacyjnej - postrzega proces wyzwalania się. Dla francuskiego 
myśliciela kluczową umiejętnością nauczyciela jest zachęcenie ucznia do samodzielnego myślenia, a nie pokazywanie mu właściwej drogi myślenia. Taka postawa, mimo że oparta na dobrych chęciach, ustanawia jednak relację hierarchiczną między tymi podmiotami. Uznanie różności intelektu i swoiste zmuszanie uczniów do myślenia sprzyja pojawieniu się sytuacji, gdy ci ostatni zaczynają używać swojego głosu do prezentowania wiedzy i zadawania pytań. Są to kluczowe umiejętności służące do samodzielnej interpretacji otaczającej rzeczywistości.

Takie podejście do ucznia wynika z Rancière’owskiego podejścia do człowieka. Autor ten dokonał inwersji słynnego powiedzenia Kartezjusza: „Myślę więc jestem” na „Jestem człowiekiem, dlatego myślę" (Rancière, 1991, s. 35-36). Według niego: „[m]yśl nie jest atrybutem substancji myślącej; jest atrybutem człowieczeństwa" (s. 36). Z tego też względu proces emancypacji nie może być dokonany przez innego człowieka. Żadna instytucja nie wyemancypuje też podmiotu. Jest to zadanie, które spoczywa wyłącznie na barkach jednostki (Biesta, 2013a), ale zadaniem szkoły i nauczycieli jest stworzenie warunków dla jego zajścia, a zatem dla uruchomienia procesu samodzielnego myślenia ucznia.

Chodzi tu o zburzenie tradycyjnej gramatyki szkoły (Tyack and Tobin, 1994), powielanej z pokolenia na pokolenie i bazującej na dominacji nauczyciela nad uczniem. Gramatykę tę tworzy porządek policyjny przeniesiony na grunt instytucji edukacyjnej, który ma odzwierciedlać porządek obowiązujący w społeczeństwie i wdrażać do zajmowania określonych pozycji i realizowania przypisanych funkcji. Uwidacznia się on chociażby w nazwie, jaką tradycyjnie nadajemy osobom uczęszczającym do szkoły. Termin „uczniowie" zakłada, że mamy do czynienia z jednostkami, którym czegoś brakuje. Zazwyczaj chodzi o wiedzę i doświadczenie. Jednak zmiana nazewnictwa i użycie formy „mówiący”, zmienia całkowicie stosunek do osoby, która jest w taki sposób określana, ponieważ zaznacza się tu jej kluczowy atrybut, a nie jego brak lub niekompletność (Biesta, 2013b).

Polityka burzy spetryfikowaną gramatykę i ustanawia nową - wyłaniającą się ze szkolnych szczelin i zakamarków (korytarzy, toalet, szatni) (Babicka-Wirkus, 2018b), będących przestrzeniami niebezpiecznymi, ponieważ to w nich dochodzi do nadawania nowych znaczeń i niestandardowych interpretacji zmieniających te obowiązujące. A zatem, jak podkreśla Jerome Bruner (2006, s. 38), „edukację należy postrzegać jako wspomaganie młodzieży w uczeniu się użycia narzędzi do wytwarzania znaczeń i konstruowania rzeczywistości w celu lepszego przystosowania do świata, w którym żyje, oraz do rozpoczęcia skutecznego procesu jego modyfikacji, zgodnie z własnymi 
wymaganiami. Edukacja może być zatem rozumiana jako pokrewna praktykom doskonalenia architektów lub budowniczych". Jest przestrzenią radykalizowania się poglądów, co jest, zdaniem Giroux (O wyznaniach..., 2010) niezbędne do walki z wszelkimi formami totalitaryzmu, monumentalizmu, ucisku i demagogii. Zapobiega również infantylizacji zarówno uczniów, jak i obywateli, odważnie sprzeciwiających się narzucanym narracjom i krytycznie podchodzących do ustanowionego porządku, który nie jest jedynym obowiązującym, lecz stanowi chwilową strukturę mogącą ulec zmianie.

Edukacja oparta na polityce jest ryzykiem, ponieważ nie tyle dopuszcza, co wymaga wielogłosu, a ten z kolei wprowadza wielość perspektyw i konieczność zmierzenia się z odmiennymi poglądami, wartościami, kulturami. Tworzenie i rekonstruowanie obowiązującego dyskursu jest zadaniem ciągłym, które bazuje na myśleniu będącym kluczową umiejętnością człowieka jako istoty ludzkiej.

\section{BIBLIOGR AFIA}

Abu-Lughod, L. (1990). The Romance of Resistance: Tracing Transformations of Power Through Bedouin Women. American Ethnologist, 17 (1), 41-55.

Babicka-Wirkus, A. (2018a). Politics of Resistance in the Context of Polish Democracy, Chowanna - maszynopis w druku.

Babicka-Wirkus, A. (2018b). Kultura(y) oporu: Działania - motywacje - przestrzeń. Warszawa: Wydawnictwo Wolters Kluwer - książka w druku.

Badiou, A. (2010). Byt i zdarzenie. Przeł. P. Pieniążek. Kraków: Wydawnictwo Uniwersytetu Jagiellońskiego.

Bauman, Z. (1991). Modernity and Ambiwalence. Cambridge: Polity Press.

Beck, U. (2004). Społeczeństwo ryzyka. W drodze do innej nowoczesności. Przeł. S. Cieśla. Warszawa: Wydawnictwo Naukowe Scholar.

Beck, U. (2012). Społeczeństwo światowego ryzyka. W poszukiwaniu utraconego bezpieczeństwa. Przeł. B. Baran, Warszawa: Wydawnictwo Naukowe Scholar.

Biesta, G. (2009). Sporadic Democracy: Education, Democracy and the Question of Inclusion. W: M.S. Katz et al. (red.), Education, Democracy, and the Moral Life, Springer Science + Business Media, B.V.

Biesta, G.J.J. (2013a). The Beautiful Risk of Education. London and New York: Routledge.

Biesta, G.J.J. (2013b). Uczący się, Student, Mówiący - o znaczeniu nazywania tych, których nauczamy. Teraźniejszość - Człowiek - Edukacja, 3 (63), 7-22.

Bruner, J. (2006). Kultura edukacji. Przeł. T. Brzostowska-Tereszkiewicz. Kraków: Towarzystwo Autorów i Wydawców Prac Naukowych UNIVERSITAS.

Bruno, V.A. and Downes, J.F. (2018). The Electoral Success of the Radical Right in Europe. Why are the Radical Right better at "capitalizing" 'Populism' than the Radical Left?, August 7, Public Seminar, http://www.publicseminar.org/2018/o8/the-electoral-success-ofthe-radical-right-in-europe/ (data dostępu: 7.08.2018).

Certeau, M. de (2008). Wynaleźć codzienność. Sztuki działania. Przeł. K. Thiel-Jańczuk, Kraków: Wydawnictwo Uniwersytetu Jagiellońskiego.

Czerepaniak-Walczak, M. (2009). Emancypacja w codzienności i przez codzienność. Egzemplifikacje edukacyjne. W: M. Dudzikowa, M. Czerepaniak-Walczak (red.), Wychowanie. Pojęcia - Procesy - Konteksty. T. V. Sopot: Gdańskie Wydawnictwo Psychologiczne, s. 93112. 
Drozdowski, R. (2009). Obraza na obrazy. Strategie społecznego oporu wobec obrazów dominujących, wydanie drugie rozszerzone. Poznań: Wydawnictwo Zysk i S-ka.

Drozdowski, R., Frąckowiak, M. (2017). Dekapilaryzacja władzy. Studia Socjologiczne, 2 (225), 9-20.

Foucault, M. (200o). Historia seksualności. Przeł. B. Banasiak, T. Komendant, K. Matuszewski, Warszawa: Wydawnictwo Czytelnik.

Franczak, J. (2017). Błądzace słowa. Jacques Rancière i filozofia literatury. Warszawa: Wydawnictwo Instytutu Badań Literackich PAN.

Freire, P. (2000). Pedagogy of the Oppressed. Przeł. M. Bergman Ramos. New York - London: Continuum.

Furedi, F. (2017). What's Happened to the University? A Sociological Exploration of its Infantilisation. London and New York: Routledge.

Janusowe oblicze sztuki upolitycznionej. Jacques Rancière w rozmowie z Gabrielem Rockhillem (2007). W: J. Rancière, Estetyka jako polityka. Przeł. J. Kutyła i P. Mościcki. Warszawa: Wydawnictwo Krytyki Politycznej.

Lyotard J.-F. (1997). Kondycja ponowoczesna. Raport o stanie wiedzy. Przeł. M. Kowalska i J. Migasiński. Warszawa: Fundacja Aletheia.

Marzenia o edukacji radyklanej. Wywiad Bernarda Murchlanda z Henrym A. Giroux (2010). Przeł. L. Witkowski. W: H.A. Giroux, L. Witkowski, Edukacja i sfera publiczna. Idee i doświadczenia pedagogiki radykalnej. Kraków: Oficyna Wydawnicza „Impuls”.

Matynia, E. (2018). Revolution, Democracy and Restoration Revisited. In Poland and beyond, July 11, Pubic Seminar, http://www.publicseminar.org/2018/o7/revolution-democracy-andrestoration-revisited (data dostępu: 11.07.2018).

McLaren, P. (2015). Życie w szkołach. Wprowadzenie do pedagogiki krytycznej. Przeł. A. Dziemianowicz-Bąk, J. Dzierzgowski, M. Starnawski. Wrocław: Wydawnictwo Naukowe Dolnośląskiej Szkoły Wyższej.

O wyznaniach, marzeniach i uczelniach (2010). Przeł. L. Witkowski. W: H.A. Giroux, L. Witkowski, Edukacja i sfera publiczna. Idee i doświadczenia pedagogiki radykalnej. Kraków: Oficyna Wydawnicza „Impuls”.

Rancière, J. (1991). The Ignorant Schoolmaster. Five Lessons in Intellectual Emancipation. Trans. K. Ross, California: Stanford University Press, Stanford.

Rancière, J. (1999). Dis-agreement: Politics and Philosophy. Trans. J. Rose. Minneapolis/London: University of Minnesota Press.

Rancière, J. (2007). Estetyka jako polityka. Przeł. J. Kutyła i P. Mościcki. Warszawa: Wydawnictwo Krytyki Politycznej.

Rosenvallon, P. (2007). Democracy Past and Future, ed. S. Moyn. Columbia: Columbia University Press.

Szaniawski, P. (2017). Sondaż: Jak Polacy oceniaja dwa lata rzadów PiS, Rzeczpospolita, 15.11.2017, https://www.rp.pl/Rzad-PiS/171119347-Sondaz-Jak-Polacy-oceniaja-dwa-lata-rzadow-PiS. html (data dostępu: 15.11.2017).

Sztuka tego, co możliwe. Jacques Rancière w rozmowie z Fulvią Carnevale i Johnem Kelseyem. W: J. Rancière, Estetyka jako polityka. Przeł. J. Kutyła i P. Mościcki. Warszawa: Wydawnictwo Krytyki Politycznej.

Tyack, D., Tobin, W. (1994). The "Grammar" of Schooling: Why Has it been so Hard to Change?, American Educational Research Journal, 31 (3), 453-479.

Žižek, S. (2007) Lekcja Rancière’a. W: J. Rancière, Estetyka jako polityka. Przeł. J. Kutyła i P. Mościcki. Warszawa: Wydawnictwo Krytyki Politycznej. 


\section{SUMMARY}

\section{Politics in education and education in politics}

The article investigates the issue of political complications in education. It indicates the dialectic relationship between them and highlights its consequences for the process of subject's emancipation. The theoretical framework of the discussion is created by Jacques Rancière's theory, especially his distinction of two forces significant to the shape of social reality - police and politics. The first one introduces relative order and apparent safety. On the other hand, the second one creates chaos and danger because it leads to unpredictable changes. However, it is a key force that changes the prevailing grammar of schooling, education and society.

KEY WORDS: education, politics, police, risk, Rancière 